\title{
Chemical signature of two Permian volcanic ash deposits within a bentonite bed from Melo, Uruguay
}

\author{
LIANE M. CALARGE ${ }^{1,2,4}$, ALAIN MEUNIER ${ }^{2}$, BRUNO LANSON ${ }^{3}$ and MILTON L.L. FORMOSO \\ ${ }^{1}$ Universidade Católica Dom Bosco, UCDB, Av. Tamandaré 6000 \\ 79117-900 Campo Grande, MS, Brasil \\ ${ }^{2}$ Université de Poitiers, Laboratoire Hydr'ASA, UMR 6532, 40 Av. du Recteur Pineau \\ 86022 - Poitiers Cedex - France \\ ${ }^{3}$ Université Joseph Fourier, LGIT, IRIGM, 5559 CNRS, BO 53X \\ 38041 - Grenoble Cedex - France \\ ${ }^{4}$ Universidade Federal do Rio Grande do Sul, Instituto de Geociências, Av. Bento Gonçalves 9500 \\ 91540-900 Porto Alegre, RS, Brasil
} Manuscript received on March 7, 2005; accepted for publication on November 22, 2005;
contributed by ALAIN MEUNIER* AND MILTON L.L. FORMOSO*

\begin{abstract}
A Permian bentonite deposit at Melo, Uruguay is composed of a calcite-cemented sandstone containing clay pseudomorphs of glass shards $(0-0.50 \mathrm{~m})$ overlying a pink massive clay deposit $(0.50-2.10 \mathrm{~m})$. The massive bed is composed of two layers containing quartz and smectite or pure smectite respectively. The smectite is remarkably homogeneous throughout the profile: it is a complex mixed layer composed of three layer types whose expandability with ethylene glycol (2EG 1EG or 0EG sheets in the interlayer zone which correspond to low-, medium- and high-charge layers respectively) varies with the cation saturating the interlayer zone. The smectite homogeneity through the profile is the signature of an early alteration process in a lagoonal water which was over saturated with respect to calcite. Compaction during burial has made the bentonite bed a K-depleted closed system in which diagenetic illitization was inhibited. Variations in major, REE and minor element abundances throughout the massive clay deposit suggest that it originated from two successive ash falls. The incompatible element abundances are consistent with that of a volcanic glass fractionated from a rhyolite magma formed in a subduction/collision geological context.
\end{abstract}

Key words: bentonite, REE, incompatible elements, mixed-layer minerals, Uruguay.

\section{INTRODUCTION}

Bentonite beds are generally formed by alteration of volcanic ash in sea, brackish or fresh waters (Grim and Güven 1978). They represent useful chronostratigraphic units that can be traced for very long distances. They have been shown to preserve a chemica magmatic signature (Wray 1995, Christi-

\footnotetext{
* Member Academia Brasileira de Ciências

Correspondence to: Dr. Alain Meunier

E-mail: alain.meunier@hydrasa.univ-poitiers.fr
}

dis et al. 1995, Clayton et al. 1996, Laviano and Mongelli 1996). Huff and Kolata (1989) showed that each bentonite bed have a unique chemical signature.

A thick Permian bentonite bed $(>2 \mathrm{~m})$ was discovered in the Melo area, Uruguay (Goñi 1952). It is nearly monomineralic and is composed of an exceptionally well-crystallized Ca-montmorillonite (Calarge et al. 2002). The purpose of the present work is to investigate the mineralogical and chem- 

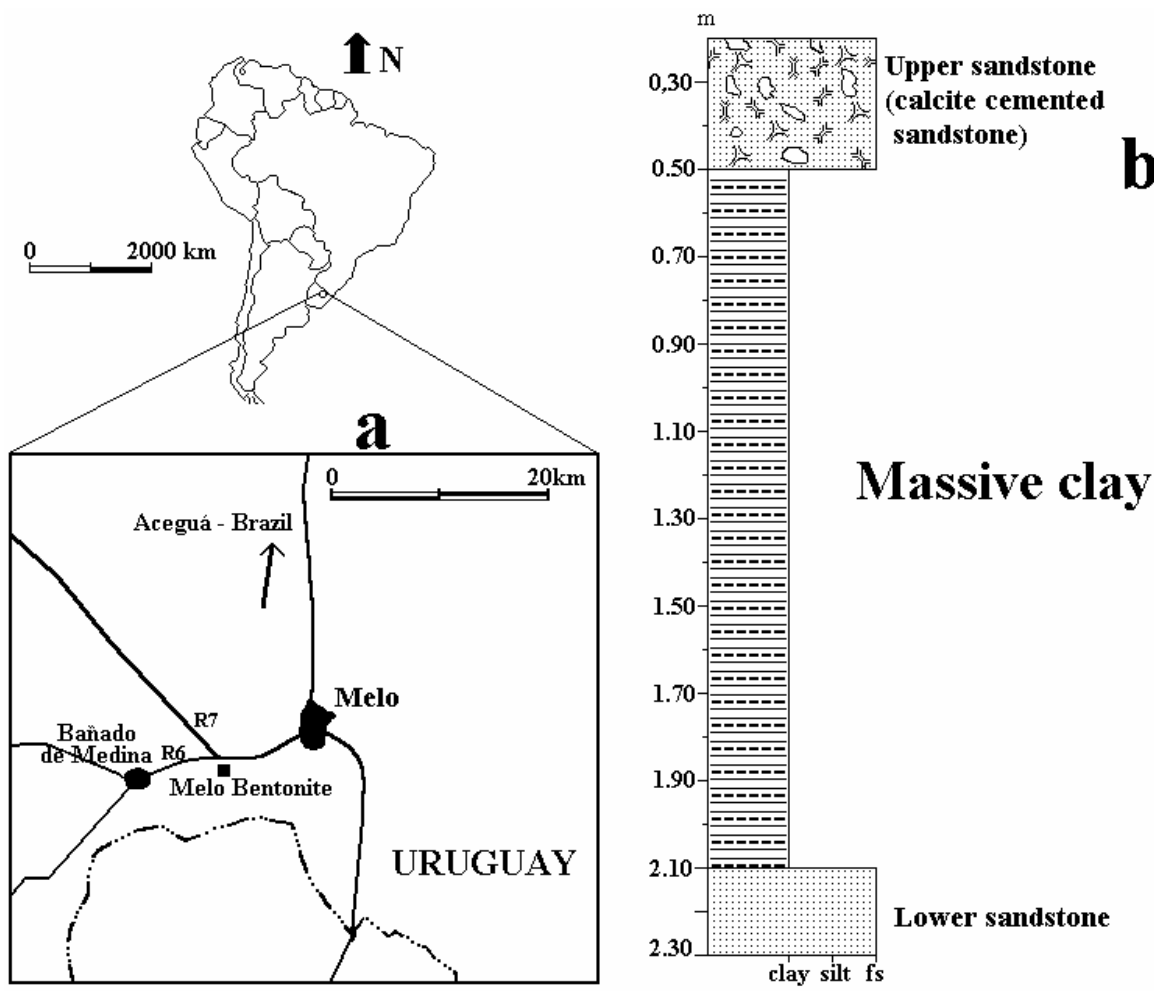

Fig. 1 - The geological setting of the bentonite bed from Melo (Uruguay). a) Location of the studied quarry. b) The studied profile.

ical composition of that bentonite bed (major and trace elements), in order to determine the possible origin of the initial volcanic ashes.

\section{GEOLOGICAL SETTING}

Permian bentonite beds have been described in different geological formations of the South East part of the Paraná basin: Rio do Rastro area in Acegua - RS - Brazil (Pintaude and Formoso 1972), Tuñas and Yaguari Formations, in the Sierras Australes, Argentina (Iñiguez et al. 1988) and the Bañado de Medina-Melo area, Uruguay (Andreis et al. 1996) respectively. A fossil reptile (Pareiasaurus americanus) discovered at Aceguá indicates that the bentonite bed can be correlated to the Daptocephalus biozone of the Karoo basin (Barberena et al. 1985) which belongs to the Upper Permian (Tatarian) according to D.C. Araújo, unpublished data.
The Melo bentonite bed crops out in a small quarry $50 \mathrm{~m}$ on the South side of the Melo to Montevideo road (Uruguay) $1 \mathrm{~km}$ from the R7 and R6 road intersection and $20 \mathrm{~km}$ from the Melo city (Fig. 1a). This bentonite bed and the Acegua one belong to the Late Permian Yaguary Formation (Tatarian) of the Bacia do Paraná (Andreis et al. 1996). The rocks are mostly sandstones of fluviatile and eolian origin alternating with mudstone deposits (red beds) which are typical lagoonal deposits formed during the Late Permian regression. Concomitantly, the volcanic activity in the northern part of Patagonia increased, peaking during the Triassic and Early Jurassic (Andreis et al. 1996). The magmas were silica-rich, and the eruptions were highly explosive and gave rise to large ash deposits (Axelrod 1981). The bentonite bed itself is a pink, massive, soft rock $1.6 \mathrm{~m}$ thick (Fig. 1b). It is overlain by a calcite-cemented sandstone $50 \mathrm{~cm}$ thick. 


\section{MATERIALS AND METHODS}

\section{XRD ANALYSES}

The bentonite samples were gently ground after drying at $60^{\circ} \mathrm{C}$ and the powders were ultrasonically dispersed in distilled water. The $<0.1 \mathrm{~m} \mu$ fraction was separated using centrifugation and $\mathrm{Ca}-$, $\mathrm{Na}$ - and $\mathrm{K}$-saturated with $1 \mathrm{~N} \mathrm{CaCl}_{2}, \mathrm{NaCl}$ or $\mathrm{KCl}$, respectively. The excess of chloride was rinsed using ethyl alcohol until no white precipitate was formed with $\mathrm{AgNO}_{3}$. An aliquot of the $\mathrm{K}$-saturated samples was $\mathrm{Ca}$-exchanged using the same procedure (K-Ca samples). Oriented and random powder mounts were prepared for each sample. XRD patterns were recorded using a Siemens D500 diffractometer $(\mathrm{Cu} \mathrm{K} \alpha$ radiation generated at $40 \mathrm{kV}$ and $40 \mathrm{~mA}$ ), equipped with a stepping motor drive on the goniometer (SOCABIM DACO system) and a Kevex PSI detector (resolution: $260 \mathrm{eV}$ ). The analytical conditions regarding angular range, scanning step size and counting time were $2-35$ and $2-75^{\circ} 2 \theta, 0.025$ and $0.040^{\circ} 2 \theta, 4$ s for oriented preparations and random powders, respectively. Detailed XRD patterns were obtained from random powders in the 32-42 (4s) and 58-64 ${ }^{\circ} 2 \alpha(8 \mathrm{~s})$ angular ranges for detailed study of $h k l$ bands characteristic of 3D structures.

Calculations of XRD patterns were performed using the MLM3C software developed by Plançon and Drits (2000). Atomic coordinates for the different layer types were set as recommended by Moore and Reynolds (1989), and the structural formula determined from chemical analyses was used to define the layer composition. The $\mathrm{d}_{00 l}$ of the different layer types was adjusted as needed within the limits given by Sato et al. (1992) to improve the quality of the fit (Table I).

Among the other parameters that had to be adjusted in the trial-and-error fitting procedure, special attention was paid to the proportions of each layer type, and to the coherent scattering domain size (N). The Reichweite parameter (Jagodzinski 1949) for these three-component MLM was limited to $\mathrm{R}=0$ (random interstratification). Because on $1 \mathrm{y}$ the main features of the experimental XRD patterns were reproduced, the estimated precision on the proportion of the different layer types is about $\pm 10 \%$. An additional parameter describes the segregation degree of the third component (Pcc).

\section{Chemical Analyses}

Major and minor elements including Rare Earth Elements (REE) were analyzed from bulk rock samples by ICP-Emission spectroscopy. Trace elements were analyzed by ICP-MS (Service d'analyses du CNRS, Nancy). The cation exchange capacity (CEC) of the $<1 \mu \mathrm{m}$ fraction was obtained from $\mathrm{Mg}^{2+}$-exchanged Ca-saturated samples, the excess of Mg salt being carefully washed out with ethanol. $\mathrm{Mg}^{2+}$ was then exchanged by $\mathrm{NH}_{4}^{+}$and analyzed in the exchange solution by atomic absorption spectrophotometry.

\section{Total Surface AREa (TSA)}

TSA measurements (external + internal surfaces) were performed on the run products $(<1 \mu \mathrm{m}$ fraction) using the adsorption of ethylene glycol monoethyl ether (EGME) according to the method recommended by Heilman et al. (1965). The total surface area (TSA) is calculated from the measured EGME mass divided by the monolayer EGME mass adsorbed per surface unit $\left(3.7710^{-4} \mathrm{~g} \mathrm{~m}^{-2}\right)$.

\section{RESULTS}

\section{PETROGRAPHY}

The studied profile is composed of two parts: From the top down they are:

1) 0 to $0.50 \mathrm{~m}$ deep: From 0 to $20 \mathrm{~cm}$, the upper sandstone is composed of angular quartz and feldspar grains, disseminated in a clay matrix and cemented by calcite. It exhibits glass shard pseudomorphs in its lower part from a depth of $20 \mathrm{~cm}$ to the sandstone-bentonite interface. Calcite cement is more abundant in the lower than in the upper part. Feldspar, mostly plagioclase, was observed only in the upper sandstone. Quartz and feldspar are fairly typical of 
TABLE I

Structural parameters of the different types of layers considered in the XRD pattern calculation of the mixed-layered minerals (Sato et al. 1992).

\begin{tabular}{c|c|c}
\hline State & Layers & $\mathrm{d}_{001}$ \\
\hline AD and EG states & Collapsed smectite (0 water or EG layer: 0W, 0EG) & $\mathrm{d}_{001} \sim 10.0 \AA$ \\
\hline \multirow{2}{*}{ AD state } & 1 water layer smectite (1W) & $12.1<\mathrm{d}_{001}<12.9 \AA$ \\
\cline { 2 - 3 } & 2 water layer smectite (2W) & $14.7<\mathrm{d}_{001}<15.5 \AA$ \\
\hline \multirow{2}{*}{ EG state } & 1EG layer smectite & $12.7<\mathrm{d}_{001}<13.9 \AA$ \\
\cline { 2 - 3 } & 2EG layer smectite & $16.5<\mathrm{d}_{001}<17.3 \mathrm{~A}$ \\
\hline
\end{tabular}

the detrital input in a deltaic environment and are consistent with the mineral composition of adjacent siliciclastic beds. The fact that vitroclastic ash structures were preserved only in the lower part of the sandstone suggests that volcanic debris were cemented early by carbonates (Jeans et al. 1977). The volcanogenic debris, as well as the detrital grains, seem to have been deposited simultaneously with the precipitation of calcite.

2) 0.50 to $2.10 \mathrm{~m}$ deep: the bentonite bed is a massive pink clay with layer a density of $1.92 \pm$ $0.05 \mathrm{~g} \mathrm{~cm}^{-3}$. Clay pseudomorphs are absent; the microstructure is typical of clay-rich sediments. Calcite and dolomite crystals are present in all the bentonite samples as trace components $(<1 \%$ in weight). The examination of thin sections of the massive clay bed did not show the presence of any magmatic phenocrysts (zircon, sanidine, micas). The coarser grains size (5 to $10 \mu \mathrm{m})$ contains only quartz.

\section{XRD ANALYSES}

Powder XRD patterns from the massive bentonite bed

XRD patterns from bulk rock powders show that the bentonite bed is mostly composed of a wellcrystallized smectite. Quartz is present in the upper part from a depth of 0.50 to $1.30 \mathrm{~m}$. Other silicates (feldspar, mica or zeolites) or carbonates commonly observed in bentonite beds are not present here. The 0.60 diffraction peak at $1.498 \AA$ shows that the smectite is dioctahedral. Its intensity suggests a large size of the coherent scattering domains in the $\mathrm{b}$ direction (Moore and Reynolds 1989), and is remarkably homogeneous throughout the profile. The Ca-saturated samples exhibit a large asymmetrical band at $2.58 \AA$ typical of completely turbostratic 3D structures (Reynolds 1992).

\section{XRD patterns of oriented samples}

$(<1 \mu$ m fraction $)$

Ca-saturated samples. As the studied samples are apparently all composed of "pure smectite", only sample $8(1.55 \mathrm{~m}$ depth) will be detailed for simplicity. The intensity and sharpness of the 001 peak in the AD and EG XRD experimental patterns is typical of a "well-crystallized" smectite (Fig. 2a-b). However, calculated patterns (Plançon and Drits 2000) give a coherent solution for the AD and EG XRD patterns for a random MLM of $2 \mathrm{~W}$ or $2 \mathrm{EG}$ (96\%) and $1 \mathrm{~W}$ or 1EG (4\%) expanded layers (Table II).

K-saturated samples. The expandability is strongly reduced: the 001 peak shifts to $11.94 \AA$ and $14.06 \AA$ in the AD and EG states, respectively (Fig. 2c-d). Calculated patterns do not give a coherent solution for the two states. Indeed, the best approximations for AD and EG are a single three component random MLM, and a mixture of two three component random MLM respectively (Fig. 2c-d).

K-Ca saturated samples. When Ca-saturated, the expandability of $\mathrm{K}$-samples increases but does not reach the values obtained in the Ca-saturated sam- 



Fig. 2-Experimental and calculated XRD patterns from oriented preparations of sample 8 (1.55m depth). a) Ca-saturated sample in the $\mathrm{AD}$ state. b) Ca-saturated sample in the EG state. c) $\mathrm{K}$ saturated sample in the AD state. d) K-saturated sample in the EG state. e) K-Ca-saturated sample in the AD state. f) K-Casaturated sample in the EG state. ples: $14.36 \AA$ and $16.27 \AA$ for $\mathrm{AD}$ and EG states respectively. This indicates that some layers have irreversibly fixed the $\mathrm{K}^{+}$cations. The calculated patterns do not give exactly the same solution for the $\mathrm{AD}$ and EG states but the best solution for both of them is a three component random and two component random MLM (Fig. 2e-f).

All samples present the same XRD pattern differences between the Ca-, K- and K-Ca-saturated preparations suggesting that the crystal structure of the smectite is remarkably constant all over the bentonite bed. It is characterized by strong layer charge heterogeneities.

Three types of layers have been considered in the mixed layering depending on their respective layer charges (Sato et al. 1992):

- high-charge layers: collapsed to $10 \AA$ after Ksaturation (0 water or ethylene glycol layer: Sm0W, Sm0EG),

- medium-charge layers:1 EG or EG in the Ksaturated state re-expanding to $2 \mathrm{EG}$ in the $\mathrm{K}$ Ca sample,

- low-charge layers: 2EG even in the K-saturated samples.

Except for the Ca-saturated samples, the calculated XRD patterns do not give similar solutions for the AD and EG states (Table II). Such a discrepancy may be due to the fact that water and ethylene glycol molecules do not have the same dipolar moment. Thus, the number of water or ethylene glycol layers depends on the $\mathrm{Ca}$ and $\mathrm{K}$ ion distribution within the interlayer zones.

\section{Chemical Analyses of the Massive BENTONITE BED}

\section{Bulk rock composition (Table III)}

Based on bulk rock chemical compositions, the massive bentonite bed appears to be divided in two zones. The upper zone $(0,5-1,55 \mathrm{~m})$ is $\mathrm{SiO}_{2}$-rich while the lower one $(1,55-2,10 \mathrm{~m})$ is $\mathrm{Al}_{2} \mathrm{O}_{3}, \mathrm{Fe}_{2} \mathrm{O}_{3}$, $\mathrm{CaO}, \mathrm{MgO}$ - rich (Figs. 3a, b, c). However, these chemical differences could be an artefact due to 
TABLE II

Composition of the two and three component mixed-layer minerals for Ca-, K- and K-Ca-saturated samples, as determined by XRD pattern calculations.

\begin{tabular}{|c|c|c|c|c|c|c|c|}
\hline cation & \multicolumn{6}{|c|}{$\mathrm{AD}$} & \multirow[t]{2}{*}{ amounts \% } \\
\hline & $2 \mathrm{~W}$ & $1 \mathrm{~W}$ & oW & $\mathrm{R}$ & $\mathrm{N}$ & Pcc & \\
\hline $\mathrm{Ca}$ & 96 & 4 & 0 & 0 & 6 & - & 100 \\
\hline $\mathrm{K}-\mathrm{Ca}$ & 50 & 20 & 30 & 0 & 5 & - & 100 \\
\hline K & 5 & 50 & 45 & 0 & 10 & - & 100 \\
\hline \multicolumn{8}{|c|}{ EG } \\
\hline & $2 \mathrm{EG}$ & $1 \mathrm{EG}$ & OEG & $\mathrm{R}$ & $\mathrm{N}$ & Pcc & \\
\hline $\mathrm{Ca}$ & 96 & 4 & 0 & 0 & 6 & & 100 \\
\hline $\mathrm{K}-\mathrm{Ca}$ & 60 & 10 & 30 & 1 & 6.5 & 0.3 & 100 \\
\hline \multirow{2}{*}{ K } & 10 & 60 & 30 & 0 & 5 & - & 70 \\
\hline & 9 & 1 & 90 & 0 & 6.5 & - & 30 \\
\hline
\end{tabular}

the presence of quartz in the upper zone as shown by powder XRD patterns. Thus, it is more appropriate to compare ratios than absolute amounts of major elements excluding $\mathrm{SiO}_{2}$. The $\mathrm{MgO} / \mathrm{CaO}$ and $\mathrm{Al}_{2} \mathrm{O}_{3} / \mathrm{MgO}$ ratios are roughly constant within the two zones but change abruptly at $-1.55 \mathrm{~m}$ (Figs. $3 \mathrm{~d}$, e). The $\mathrm{MgO} / \mathrm{MgO}+\mathrm{Fe}_{2} \mathrm{O}_{3}$ ratio decreases from bottom to top forming two successive parabolic trends joining at $-1.55 \mathrm{~m}$ (Fig. 3f). To the chemical changes observed at $-1.55 \mathrm{~m}$ corresponds also changes in physical properties of the clay minerals. Indeed, the average TSA value (Ca-saturated samples) is lower in the upper part: 597.90 instead of $596.64 \mathrm{~m}^{2} \mathrm{~g}^{-1}$. Such a convergence between chemical and physical properties strongly suggests that the bentonite bed is composed of two layers, each of them being homogeneous in itself (constant chemical composition and TSA values).

\section{Trace elements and REE abundances}

Trace and REE element concentrations (Table IV) vary with depth. For simplicity, elements exhibiting the same concentration profiles have been grouped. Four groups were distinguished: 1) identical concentrations amounts in the two layers $(\mathrm{Co}, \mathrm{Ga}, \mathrm{Hf}$, $\mathrm{Nb}, \mathrm{Rb}, \mathrm{Sn}, \mathrm{Sr}, \mathrm{Ta}, \mathrm{Th}, \mathrm{Zr}$ ). This group is represented by the $\mathrm{Sr}$ concentration profile (Fig. 4a);
2) higher concentrations in the bottom layer $(\mathrm{Cs}$, $\mathrm{Cu}, \mathrm{Ge}, \mathrm{In}, \mathrm{Pb}, \mathrm{U}, \mathrm{Zn}$ ). This group is represented by the Cs concentration profile (Fig. 4b); 3) higher concentrations in the upper layer $(\mathrm{Ba}, \mathrm{Be})$. This group is represented by the $\mathrm{Ba}$ concentration profile (Fig. 4c); 4) identical patterns with a larger range of variation in the bottom layer $(\mathrm{Ce}, \mathrm{Dy}, \mathrm{Er}$, Eu, Gd, Ho, La, Lu, Nd, Pr, Sb, Sm, Tb, Tm, Y, $\mathrm{Yb})$. This group is represented by the Dy concentration profile (Fig. 4d). The total REE concentrations in the studied samples vary from 130 to 570 ppm. However, in spite of these large differences, the REE pattern abundances, normalized to chondrite, are constant in shape throughout the profile (Fig. 4e). They all show the negative Eu anomaly.

\section{DISCUSSION}

The ORIGIN OF THE VolcaniC Glass

As bentonites result from an alteration process, the chemical composition of the initial volcanic ash is modified through gains and losses of elements with respect to the altering solutions. Christidis (1998) showed that these chemical exchanges depend on the composition of the volcanic debris and the water/rock ratio in a marine system. Consequently, it is excluded to use the proportions of the major elements to determine the original glass composition. 

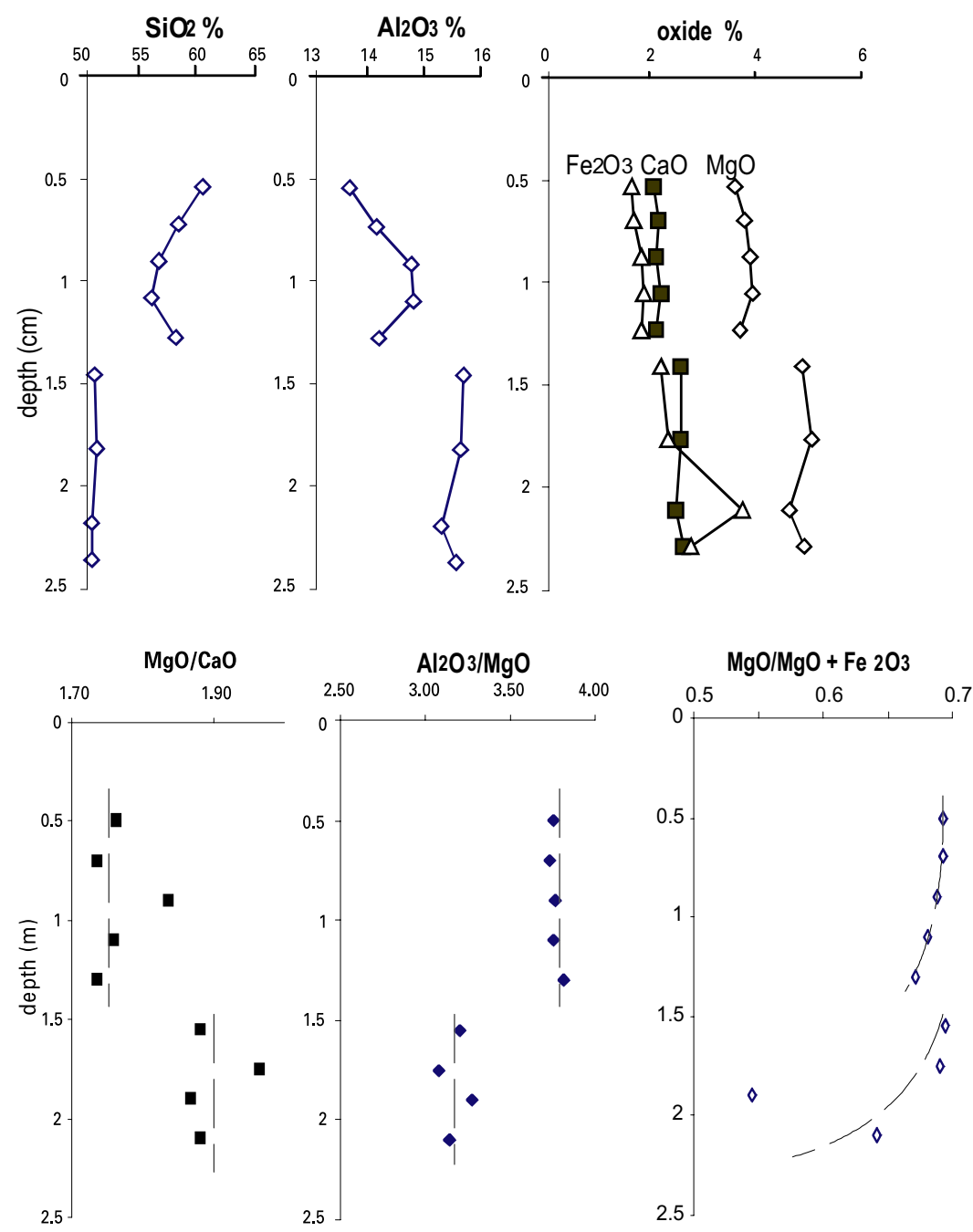

Fig. 3 -Evolution of the major chemical components throughout the profile. a) Variation of absolute values vs depth (m). b) Variation of $\mathrm{MgO} / \mathrm{CaO}, \mathrm{Al}_{2} \mathrm{O}_{3} / \mathrm{MgO}$ and $\mathrm{MgO} / \mathrm{MgO}+\mathrm{Fe}_{2} \mathrm{O}_{3}$ ratios vs depth (m).

Christidis (1998) showed that only the ratios of the relatively immobile elements in the bulk bentonite rock (smectite + accessory minerals) are potential indicators. Such attempts at chemical fingerprinting have had mixed success because alteration processes have been shown to variably modify the relative proportions of most elements. However, using ratios of the so-called "immobile" elements such as $\mathrm{Ti}, \mathrm{Zr}, \mathrm{Y}$ and $\mathrm{Nb}$ in the projection of Winchester and Floyd (1977), the studied samples are in the rhyolite composition field or near its boundary with comendite/pantellerite one (Fig. 4f). The Eu anomaly is commonly attributed to the removal of Eu by plagioclase feldspar during fractionation of the melt. This anomaly is typical of evolved magmas.

Considering the Permian age of the bentonite deposit, the source of the volcanic glass could be related to a volcanic activity triggered by the collision of the northern active margin of the Patagonian micro-plate with the South American continental plate (Ramos 1984). 

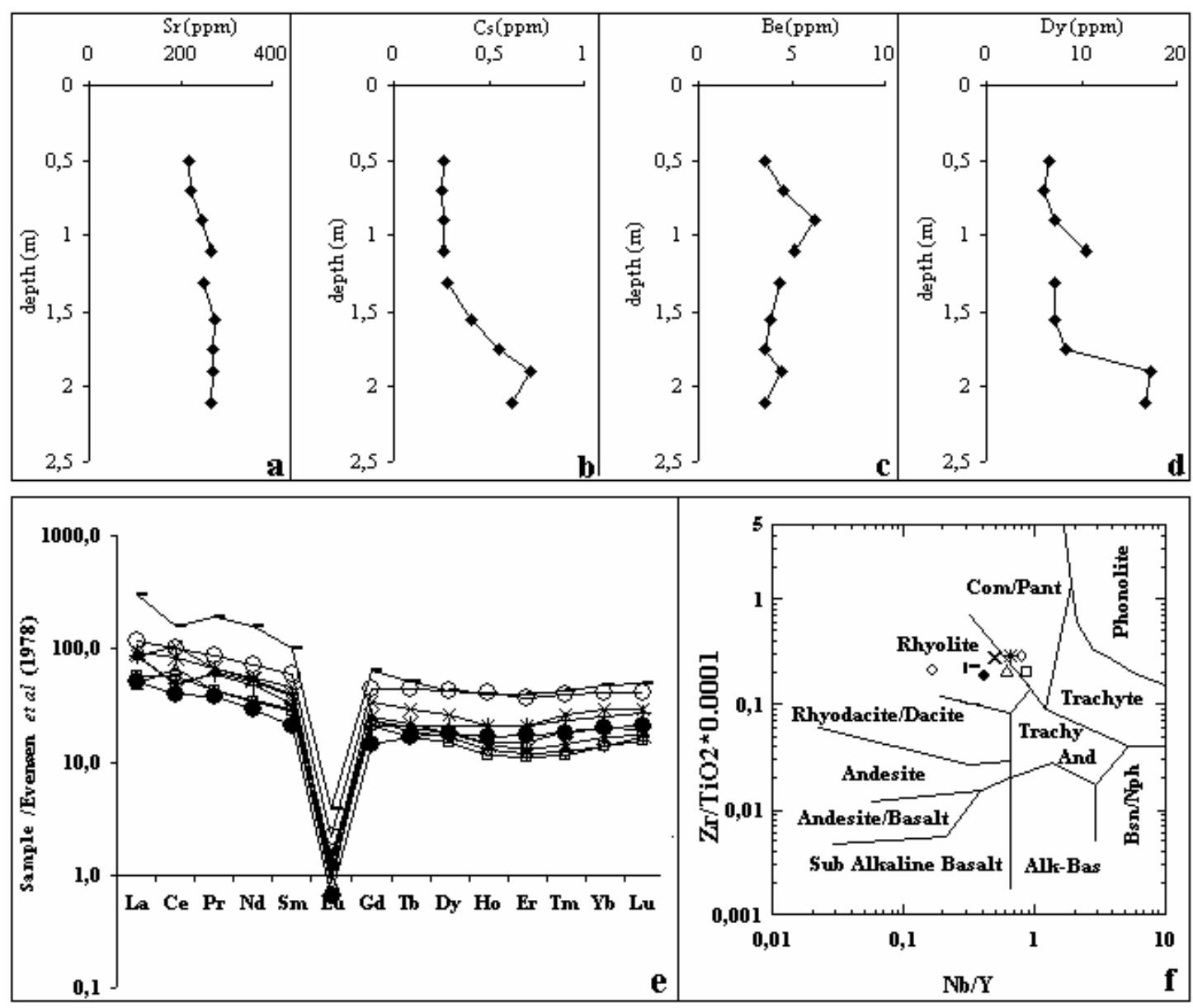

Legend of the Fig $4 \mathrm{e}$ and $4 \mathrm{f}:(0) 0.50 \mathrm{~m}_{i}(\square) 0.70 \mathrm{~m}_{i}(\Delta) 0.90 \mathrm{~m}_{i}(X) 1.10 \mathrm{~m}_{i}(*) 1.30 \mathrm{~m}_{i}(\bullet) 1.55 \mathrm{~m}_{i}(1) 1.75 \mathrm{~m}_{i}(-) 1.90 \mathrm{~m}_{i}(\bullet) 2.10 \mathrm{~m}$

Fig. 4 - Trace and REE elements. The variations of trace element amounts vs depth are given for four representative elements: a) Sr for group 1 (identical concentrations in the lower and upper layers: $\mathrm{Co}, \mathrm{Ga}, \mathrm{Hf}, \mathrm{Nb}, \mathrm{Rb}, \mathrm{Sn}, \mathrm{Sr}, \mathrm{Ta}, \mathrm{Th}, \mathrm{Zr}$ ); b) Cs for group 2 (higher concentrations in the bottom layer: $\mathrm{Cs}, \mathrm{Cu}, \mathrm{Ge}, \mathrm{In}, \mathrm{Pb}, \mathrm{U}, \mathrm{Zn}$ ); c) Be for group 3 (higher concentrations in the upper layer: $\mathrm{Ba}, \mathrm{Be}$ ); d) Dy for group 4 (identical patterns with larger variation range in the bottom layer: $\mathrm{Ce}, \mathrm{Dy}, \mathrm{Er}, \mathrm{Eu}, \mathrm{Gd}, \mathrm{Ho}, \mathrm{La}, \mathrm{Lu}, \mathrm{Nd}, \mathrm{Pr}, \mathrm{Sb}, \mathrm{Sm}, \mathrm{Tb}$, $\mathrm{Tm}, \mathrm{Y}, \mathrm{Yb}$ ), e) REE patterns of bentonite samples normalized to CI chondrite (Evensen 1978). f) Position of the bentonite samples in the diagram of Winchester and Floyd (1977).

\section{The Volcanic Glass to Smectite Reaction}

During alteration, the rhyolitic ignimbrite lost $\mathrm{Sr}$ and $\mathrm{Rb}$, whereas $\mathrm{Zr}$ and $\mathrm{Th}$ display a residual enrichment. In the present case, those elements remained constant throughout the profile (group 1, represented by the $\mathrm{Sr}$ concentration profile type, Fig. 4a), indicating that the chemical balance of the volcanic glass-to-smectite reaction was perfectly constant throughout the deposit. This means that the water/rock ratio was high enough for the reaction to be complete. It also suggests that no other significant chemical reaction has subsequently affected the bentonite deposit.

Geological studies of the sedimentary environment have shown that the volcanic ash was deposited in a lacustrine system (Andreis et al. 1996). The preservation of smectite pseudomorphs of glass shards in the upper sandstone confirms that volcanic ashes were deposited into low energy envi- 
TABLE III

Bulk chemical analyses (\%), cation exchange capacity (CEC) and total surface area (TSA) of samples from the massive bentonite bed.

\begin{tabular}{c|c|c|c|c|c|c|c}
\hline depth (m) & $\mathrm{SiO}_{2}$ & $\mathrm{Al}_{2} \mathrm{O}_{3}$ & $\mathrm{Fe}_{2} \mathrm{O}_{3}$ & $\mathrm{MnO}$ & $\mathrm{MgO}$ & $\mathrm{CaO}$ & $\mathrm{Na}_{2} \mathrm{O}$ \\
\hline 0.50 & 60.65 & 13.69 & 1.67 & 0.04 & 3.65 & 2.07 & $<$ L.D. \\
\hline 0.70 & 58.48 & 14.18 & 1.74 & 0.16 & 3.80 & 2.19 & $<$ L.D. \\
\hline 0.90 & 56.72 & 14.80 & 1.84 & 0.26 & 3.93 & 2.14 & 0.07 \\
\hline 1.10 & 56.10 & 14.81 & 1.90 & 0.49 & 3.94 & 2.24 & 0.07 \\
\hline 1.30 & 58.26 & 14.22 & 1.87 & 0.35 & 3.73 & 2.15 & 0.05 \\
\hline 1.55 & 51.22 & 15.68 & 2.22 & 0.11 & 4.89 & 2.60 & 0.10 \\
\hline 1.75 & 51.43 & 15.66 & 2.35 & 0.10 & 5.09 & 2.59 & 0.06 \\
\hline 1.90 & 51.12 & 15.30 & 3.77 & 0.04 & 4.67 & 2.50 & 0.10 \\
\hline 2.10 & 51.09 & 15.57 & 2.79 & 0.08 & 4.95 & 2.63 & 0.07 \\
\hline
\end{tabular}

TABLE III (continuation)

\begin{tabular}{c|c|c|c|c|c|c|c}
\hline depth $(\mathrm{m})$ & $\mathrm{K}_{2} \mathrm{O}$ & $\mathrm{TiO}_{2}$ & $\mathrm{P}_{2} \mathrm{O}_{5}$ & LOI & Total & $\mathrm{TSA}_{\left(\mathrm{m}^{2} \mathrm{~g}^{-1}\right)}$ & $\mathrm{CEC}\left(\mathrm{cmol} \mathrm{kg}^{-1}\right)$ \\
\hline 0.50 & 0.10 & 0.07 & < L.D. & 17.89 & 99.83 & 539.07 & 98.56 \\
\hline 0.70 & 0.11 & 0.08 & < L.D. & 19.06 & 99.80 & 558.46 & 104.48 \\
\hline 0.90 & 0.10 & 0.08 & < L.D. & 19.94 & 99.88 & 646.81 & 105.07 \\
\hline 1.10 & 0.11 & 0.07 & 0.05 & 20.12 & 99.90 & 568.17 & 112.04 \\
\hline 1.30 & 0.10 & 0.06 & $<$ L.D. & 19.04 & 99.83 & 546.99 & 98.72 \\
\hline 1.55 & 0.09 & 0.10 & 0.06 & 22.78 & 99.85 & 605.63 & 108.62 \\
\hline 1.75 & 0.11 & 0.08 & $<$ L.D. & 22.56 & 100.03 & 576.87 & 86.92 \\
\hline 1.90 & 0.15 & 0.11 & 0.06 & 22.00 & 99.82 & 601.70 & 109.43 \\
\hline 2.10 & 0.14 & 0.09 & < L.D. & 22.43 & 99.84 & 302.36 & 87.10 \\
\hline
\end{tabular}

ronments where current sorting and redistribution were minimal (Jeans et al. 2000). Evaporation concentrated seawater in the lagoon until the conditions for calcite precipitation were attained. The formation of montmorillonite instead of zeolite suggests that the water was not highly saline or alkaline as happens in playas. The formation of montmorillonite from rhyolitic or dacitic glass produces opal CT (Altaner and Grim 1990). In the present case, the absence of opal CT or secondary quartz indicates that oversaturation with respect to amorphous silica was not attained. The lack of zeolite and opal CT suggests that the solutions were continuously diluted by fresh water from rivers forming the del- taic environment. The presence of small amounts of calcite and dolomite crystals in the bentonite samples indicates that calcium concentration was lower than alkalinity (Hardie and Eugster 1970). These conditions favor the formation of $\mathrm{Mg}$ smectites.

Compared to the chemical compositions of montmorillonite formed from rhyolite ash altered in a lacustrine environment (Zielinski 1982), the Melo bentonite presents a number of similarities: 1 ) depletion in $\mathrm{Rb}, \mathrm{Na}, \mathrm{K}$ and $\mathrm{U}$; 2) conservation of Th, Ta and Hf; 3) enrichment in Ca, $\mathrm{Mg}$, Sr. These facts point to the influence of fresh water input in the lagoon. It is remarkable that, except for $\mathrm{U}$, most of the trace elements involved in this mass balance 
TABLE IV

Trace element abundances (ppm) of samples from the massive bentonite bed.

\begin{tabular}{|c|c|c|c|c|c|c|c|c|c|}
\hline & $0.5 \mathrm{~m}$ & $0.7 \mathrm{~m}$ & $0.9 \mathrm{~m}$ & $1.1 \mathrm{~m}$ & $1.3 \mathrm{~m}$ & $1.55 \mathrm{~m}$ & $1.75 \mathrm{~m}$ & $1.9 \mathrm{~m}$ & $2.1 \mathrm{~m}$ \\
\hline As & 7.50 & 7.67 & 8.02 & 14.35 & 8.95 & 7.90 & 9.81 & 23.88 & 26.99 \\
\hline $\mathrm{Ba}$ & 336.65 & 361.87 & 629.90 & 893.01 & 669.07 & 318.18 & 314.36 & 270.31 & 306.90 \\
\hline $\mathrm{Be}$ & 3.54 & 4.56 & 6.19 & 5.11 & 4.31 & 3.90 & 3.56 & 4.43 & 3.54 \\
\hline $\mathrm{Bi}$ & 0.29 & 0.23 & 0.24 & 0.32 & 0.27 & 0.39 & 0.28 & 0.74 & 0.47 \\
\hline $\mathrm{Cd}$ & $<$ L.D. & $<$ L.D. & $<$ L.D. & < L.D. & $<$ L.D. & $<$ L.D. & < L.D. & $<$ L.D. & $<$ L.D. \\
\hline $\mathrm{Ce}$ & 57.92 & 68.33 & 80.13 & 126.19 & 99.68 & 46.54 & 59.67 & 188.47 & 122.36 \\
\hline $\mathrm{Co}$ & 5.13 & 1.16 & 7.66 & 3.89 & 5.00 & 2.70 & 2.78 & 5.99 & 4.17 \\
\hline $\mathrm{Cr}$ & 5.93 & $<$ L.D. & 5.59 & $<$ L.D. & $<$ L.D. & $<$ L.D. & $<$ L.D. & $<$ L.D. & $<$ L.D. \\
\hline Cs & 0.26 & 0.26 & 0.26 & 0.27 & 0.28 & 0.41 & 0.55 & 0.72 & 0.63 \\
\hline $\mathrm{Cu}$ & < L.D. & < L.D. & < L.D. & < L.D. & < L.D. & 7.77 & 8.16 & 10.84 & 9.35 \\
\hline Dy & 6.60 & 6.00 & 7.24 & 10.57 & 7.11 & 7.11 & 8.31 & 17.24 & 16.73 \\
\hline $\mathrm{Er}$ & 3.09 & 2.89 & 3.84 & 5.45 & 3.34 & 4.50 & 5.34 & 10.07 & 9.66 \\
\hline $\mathrm{Eu}$ & 0.12 & 0.12 & 0.09 & 0.13 & 0.14 & 0.07 & 0.10 & 0.37 & 0.22 \\
\hline $\mathrm{Ga}$ & 24.82 & 27.79 & 29.12 & 28.68 & 27.03 & 30.37 & 29.31 & 29.52 & 29.99 \\
\hline Gd & 8.03 & 7.05 & 7.80 & 11.68 & 8.51 & 4.85 & 7.17 & 21.64 & 15.17 \\
\hline $\mathrm{Ge}$ & 0.69 & 0.82 & 0.89 & 1.02 & 1.07 & 3.72 & 3.62 & 2.53 & 3.22 \\
\hline Hf & 7.81 & 8.17 & 9.39 & 8.93 & 8.24 & 8.95 & 8.19 & 9.39 & 8.73 \\
\hline Ho & 1.14 & 1.02 & 1.31 & 1.84 & 1.29 & 1.49 & 1.87 & 3.46 & 3.59 \\
\hline In & 0.11 & 0.11 & 0.12 & 0.13 & 0.11 & 0.14 & 0.14 & 0.14 & 0.15 \\
\hline $\mathrm{La}$ & 39.31 & 26.07 & 22.43 & 39.29 & 43.51 & 23.85 & 39.54 & 136.58 & 53.98 \\
\hline $\mathrm{Lu}$ & 0.62 & 0.59 & 0.74 & 1.11 & 0.66 & 0.81 & 1.04 & 1.87 & 1.55 \\
\hline Mo & < L.D. & $<$ L.D. & < L.D. & 0.45 & < L.D. & < L.D. & < L.D. & < L.D. & $<$ L.D. \\
\hline $\mathrm{Nb}$ & 21.93 & 23.10 & 19.41 & 20.87 & 22.46 & 18.64 & 17.61 & 20.70 & 17.40 \\
\hline $\mathrm{Nd}$ & 43.82 & 29.04 & 29.74 & 46.60 & 45.27 & 24.95 & 41.16 & 133.49 & 60.70 \\
\hline $\mathrm{Ni}$ & $<$ L.D. & $<$ L.D. & $<$ L.D. & < L.D. & $<$ L.D. & < L.D. & < L.D. & $<$ L.D. & $<$ L.D. \\
\hline $\mathrm{Pb}$ Total & 6.75 & 10.81 & 23.80 & 34.78 & 27.16 & 61.74 & 45.78 & 50.47 & 46.81 \\
\hline $\operatorname{Pr}$ & 11.33 & 7.68 & 7.68 & 11.89 & 11.95 & 6.82 & 10.81 & 34.09 & 15.86 \\
\hline $\mathrm{Rb}$ & 5.93 & 5.21 & 6.76 & 6.22 & 6.01 & 4.81 & 6.23 & 7.39 & 6.83 \\
\hline $\mathrm{Sb}$ & 0.36 & 0.13 & 0.13 & 0.17 & 0.16 & 0.41 & 0.47 & 1.58 & 0.55 \\
\hline $\mathrm{Sm}$ & 10.43 & 7.54 & 7.75 & 12.56 & 10.55 & 5.66 & 8.69 & 27.44 & 15.98 \\
\hline $\mathrm{Sn}$ & 6.58 & 6.87 & 7.51 & 7.59 & 7.32 & 7.69 & 7.50 & 5.88 & 7.45 \\
\hline $\mathrm{Sr}$ & 216.97 & 223.44 & 246.65 & 266.84 & 252.06 & 275.24 & 272.13 & 272.67 & 268.00 \\
\hline $\mathrm{Ta}$ & 1.91 & 2.03 & 2.05 & 2.08 & 1.95 & 2.12 & 2.11 & 1.77 & 2.21 \\
\hline $\mathrm{Tb}$ & 1.11 & 0.99 & 1.21 & 1.78 & 1.29 & 0.99 & 1.26 & 3.04 & 2.65 \\
\hline $\mathrm{Th}$ & 20.58 & 20.87 & 20.99 & 23.12 & 21.15 & 25.14 & 23.61 & 21.00 & 25.18 \\
\hline $\mathrm{Tm}$ & 0.49 & 0.45 & 0.71 & 1.01 & 0.56 & 0.70 & 0.90 & 1.64 & 1.55 \\
\hline $\mathrm{U}$ & 0.68 & 0.51 & 0.78 & 0.82 & 0.52 & 1.25 & 1.29 & 1.83 & 1.71 \\
\hline $\mathrm{V}$ & 52.37 & 22.84 & 18.20 & 24.96 & 16.30 & 18.16 & 20.50 & 22.92 & 39.73 \\
\hline $\mathrm{W}$ & 0.57 & 0.28 & 1.10 & 1.29 & 1.02 & 0.34 & 0.20 & 0.93 & 0.50 \\
\hline $\mathrm{Y}$ & 27.97 & 27.24 & 31.85 & 44.34 & 32.30 & 45.93 & 55.54 & 107.46 & 103.54 \\
\hline $\mathrm{Yb}$ & 3.41 & 3.40 & 4.98 & 7.43 & 4.22 & 5.01 & 6.39 & 11.82 & 10.32 \\
\hline $\mathrm{Zn}$ & 101.63 & 112.30 & 118.11 & 128.42 & 109.76 & 142.08 & 131.76 & 127.66 & 133.86 \\
\hline $\mathrm{Zr}$ & 159.94 & 163.96 & 172.63 & 182.10 & 171.97 & 175.95 & 170.74 & 231.93 & 181.71 \\
\hline
\end{tabular}

$<$ D.L. - Amount lower than the detection limits. 
( $\mathrm{Rb}, \mathrm{Th}, \mathrm{Ta}, \mathrm{Hf}, \mathrm{Sr}$ ) belong to group 1 (represented by the $\mathrm{Sr}$ concentration profile type, Fig. 4a). Therefore, whatever the chemical variations in the profile were, the formation of montmorillonite happened in identical conditions throughout the bentonite deposit. This process is different from the progressive diagenetic transformation of volcanic glass to smectite in deep-sea environments (Hein and Scholl 1978). In the latter case, polyphased assemblages are produced while some glass relics survive. Further, the smectitic minerals produced contain only a few illite layers.

The absence of any K-bearing mineral phase in the Melo bentonite implies that excess $\mathrm{Si}^{4+}$ and $\mathrm{K}^{+}$ions were leached out of the system. During burial, as compaction increases the density of the sediment and decreases its permeability, the bentonite bed became progressively more compact and formed a closed K-depleted chemical system in which the smectite-to-illite diagenetic reaction was inhibited. This explains why there are no illitesmectite mixed layers as commonly observed in Kbentonites (Huff and Türkmenoglü 1981, Altaner et al. 1984). Nevertheless, even though illite is not formed, charge heterogeneities still appear, as shown by the effects of $\mathrm{K}$ - and $\mathrm{K}$-Ca-saturations on XRD patterns. The Melo smectite is an interstratification of expandable layers that have different layer charge.

In summary, the volcanic glass was probably altered shortly after deposition in lagoonal water that was oversaturated with respect to calcite. These particular conditions were stable during the ash fall, which explains the mineralogical homogeneity throughout the profile. Afterwards, diagenetic conditions did not modify the composition of the smectite significantly because the compacting bentonite bed became progressively a Ca-rich $\mathrm{K}$-depleted closed system that was improper to illitization. The compaction process destroyed the volcanoclastic structures, except in the upper sandstone where these structures were preserved by the rigidity of the calcite cement.
GRADING IN A SINGLE ASH FALL OR IN Two Ash FALLS?

The abrupt variation of major component concentrations at the depth $1.55 \mathrm{~m}$ (Fig. 3) suggests that the bentonite bed is composed of two parts. This is confirmed by variations in trace element abundances elements with greater or lower abundance in the upper layer, i.e., $\mathrm{Cs}, \mathrm{Cu}, \mathrm{Ge}, \mathrm{In}, \mathrm{Pb}, \mathrm{U}$, and $\mathrm{Zn}$, (group 2, represented by the Cs concentration profile type, Fig. 4b) or Ba and Be (group 3, represented by the Be concentration profile type, Fig. 4c) and Dy concentration profile type for group 4 (Fig. 4d) respectively. Compared to sample 8 (1.55 $\mathrm{m}$ depth) which has the lowest REE abundance, most of the upper ones appear to be more HREE depleted than the lower ones (Fig. 4e). The $\mathrm{La} / \mathrm{Yb}$ ratio varies from 3,04 to 7,80. This means that the HREE were partially leached (Christidis 1998). The four groups of elements are shown in Figures 5a to 5d.

There variations in the amounts of major and trace elements are significant. They suggest that either the chemical composition of the magmatic products has varied during a rhythmic volcanic eruption, or that two successive eruptions produced the ash falls. In either scenario, the two ash deposits were superimposed before the transformation of glass into smectite. The lack of any detrital deposit between the two parts militates for a single rhythmic event. Unfortunately, as magmatic phenocrysts and particularly heavy minerals have not been found in the massive bentonite bed, it is almost impossible to discriminate between the two alternatives.

\section{A Possible Rhyolitic Composition}

Even if most of the major element abundances are modified during the transformation of volcanic glass to smectite, the less mobile ones $\left(\mathrm{Fe}^{3+}, \mathrm{Al}\right)$ suggest that the initial ash composition was closer to rhyolite than to rhyodacite or andesite. This is confirmed by the so-called "immobile" elements such as $\mathrm{Ti}, \mathrm{Zr}, \mathrm{Y}$ and $\mathrm{Nb}$. Using ratios rather than absolute values, the projection from Winchester and Floyd (1977) can be applied to altered volcanic ma- 

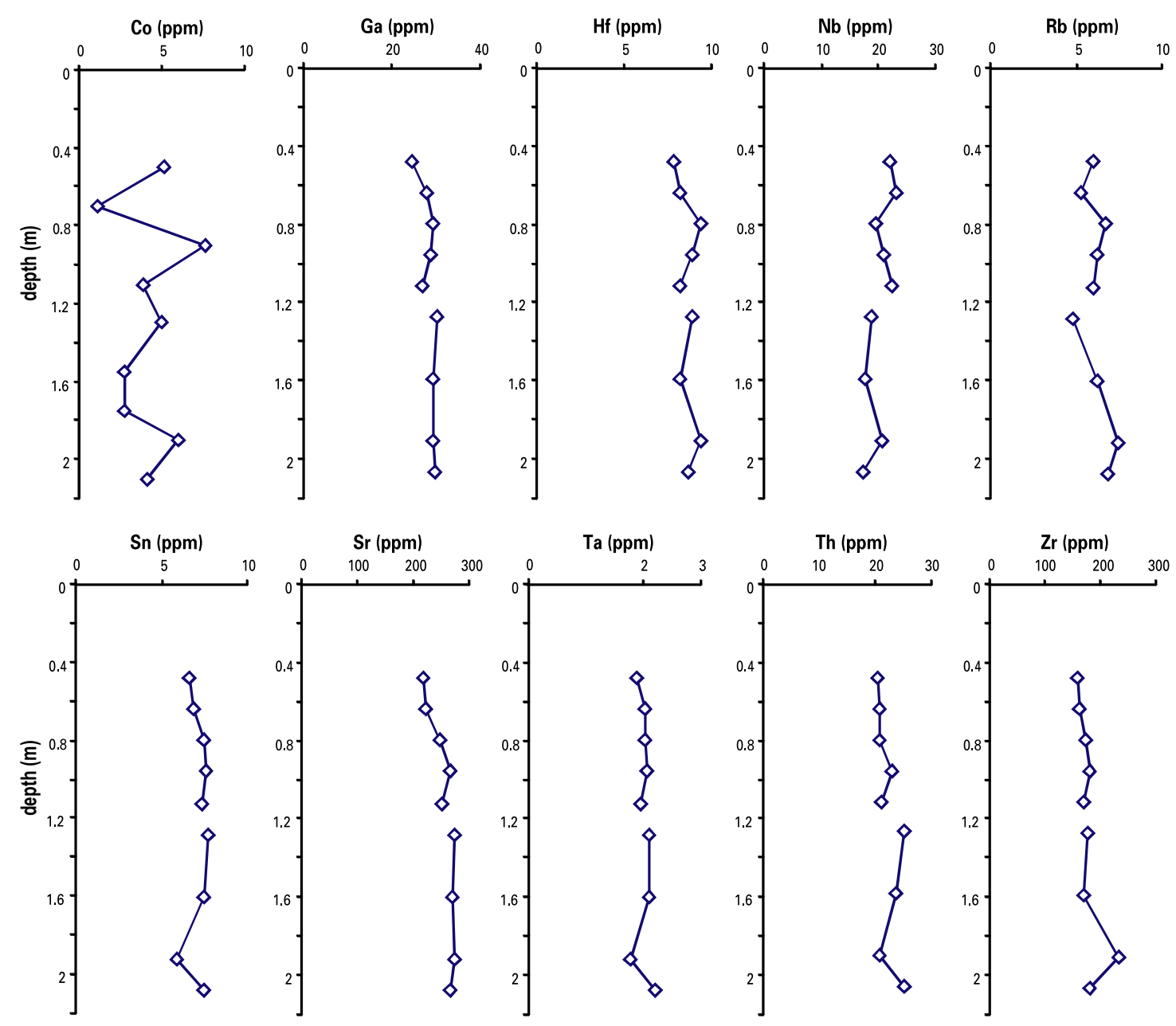

Fig. 5a-GROUP 1

terials such as bentonites (Huff et al. 1993). In the present case, most of the studied samples are in the rhyolite composition field or near its boundary with comendite/pantellerite (Fig. 4f). The Eu anomaly is commonly attributed to the removal of Eu by plagioclase feldspar during fractionation of the melt. This anomaly is typical of evolved magmas.

Therefore, the Melo bentonite probably derived from ash resulting from an explosive fragmentation of the residual melt, after plagioclase feldspar crystallized from a rhyolitic magma. This is confirmed by spider diagrams (Figs. 5a to 5d) normalized to a subduction/collision rhyolite glass (Juteau and Maury 1997). Considering that the neg- ative $\mathrm{Rb}, \mathrm{K}$ and $\mathrm{Eu}$ anomalies are related to magmatic differentiation and plagioclase crystallization respectively, it appears that the bentonite patterns are close to the reference line.

\section{CONCLUSION}

Based on its chemical characteristics, the thick Melo bentonite bed resulted probably from the superposition of two different volcanic ash deposits. Using the distribution of incompatible elements, the composition of the original glass appears to be similar to that of glass resulting from the fractionation of a rhyolitic magma in a subduction/collision 

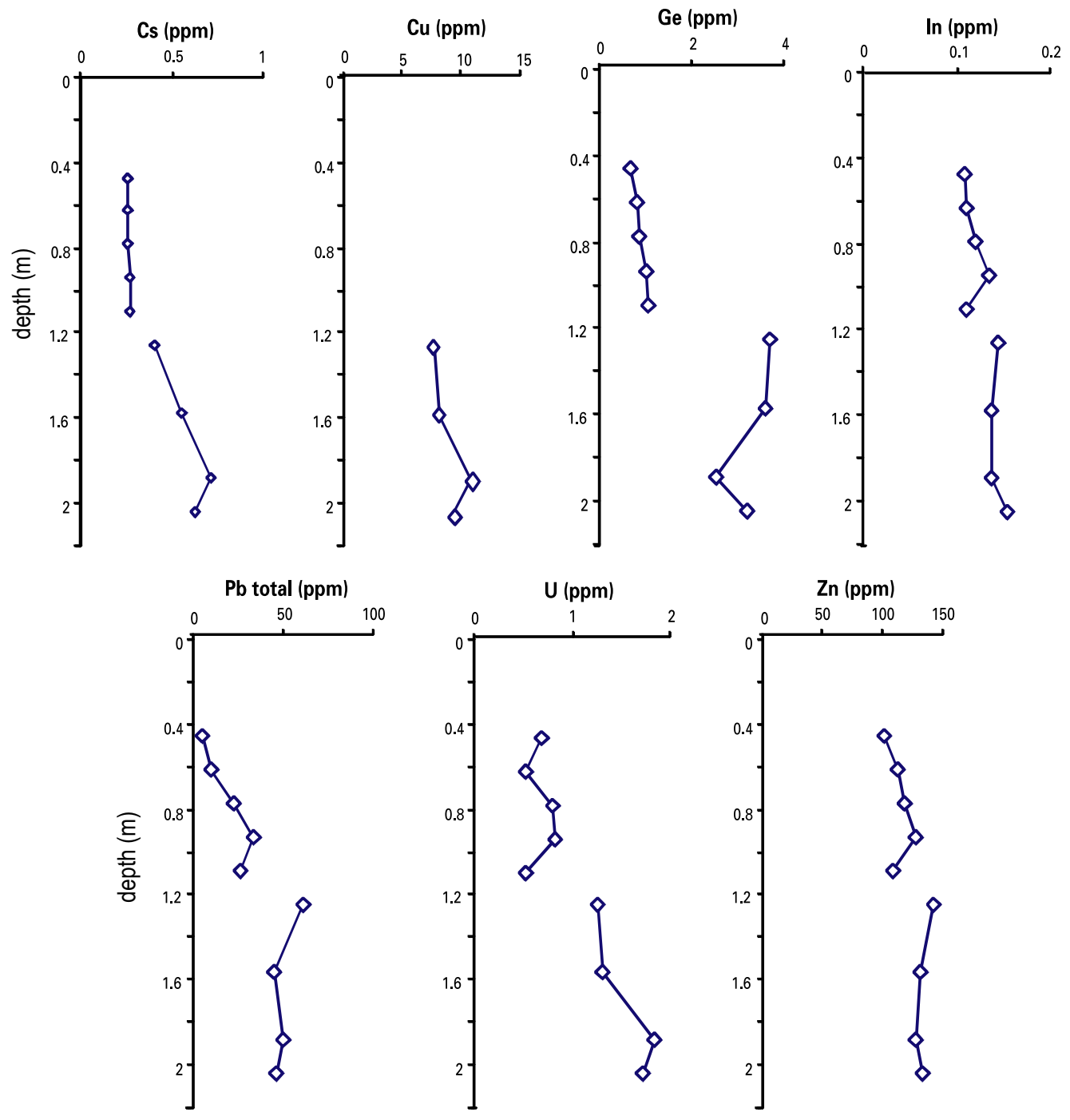

Fig. $5 b-$ GROUP 2

setting. It is to be noticed that the chemical differences between the two ash falls were not sufficient to cause a mineralogical contrast. The high homogeneity of the smectitic minerals throughout the massive bentonite suggests that the volcanic glass has been altered in stable chemical conditions imposed by the sedimentary environment.

\section{ACKNOWLEGMENTS}

L. Calarge has benefited of a grant from the French-Brazilian cooperation agreement Coorde- nação de Aperfeiçoamento de Pessoal de Nível Superior (CAPES) - Comité Français d'Evaluation de la Coopération Universitaire avec le Brésil (COFECUB). Funding for analyses was provided by Unité Mixte de Recherche (UMR) 6532 Centre National de la Recherche Scientifique (CNRS).

\section{RESUMO}

Um depósito Permiano de bentonita em Melo, Uruguai, é composto por um arenito com cimento calcítico contendo pseudomorfos de argila sobre detritos vítreos 

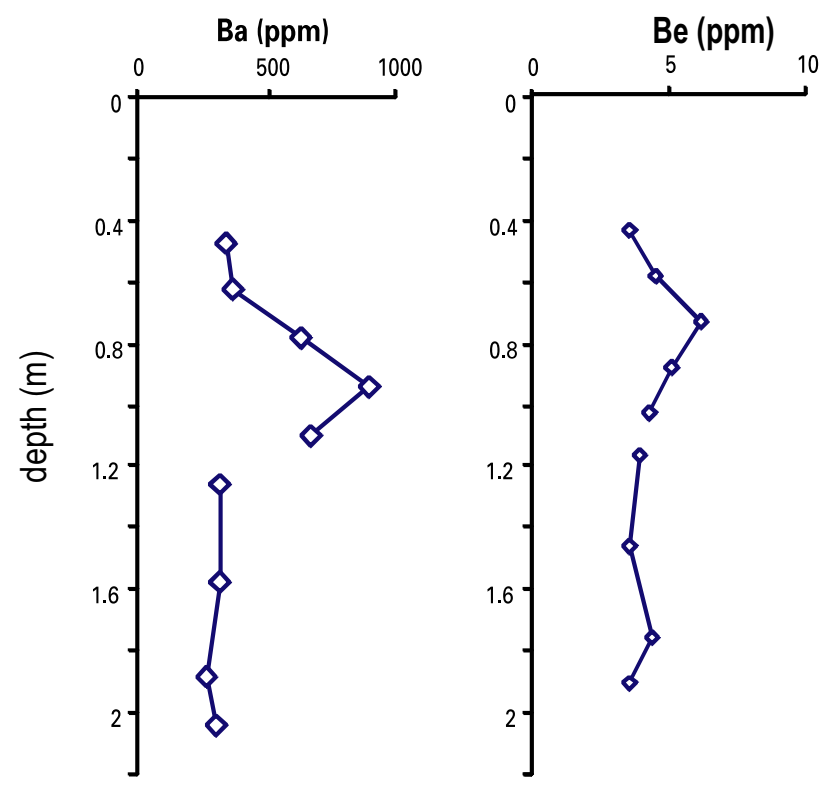

Fig. 5c-GROUP 3

(0-0.50 m) superpostos a um deposito maciço de argila rosado $(0.50-2.10 \mathrm{~m})$. A camada maciça é composta por dois níveis contendo quartzo e esmectita ou esmectita pura, respectivamente. A homogeneidade de esmectita ao longo do perfil é notável: trata-se de um interestratificado composto de três tipos de camadas, cuja expansibilidade com etileno-glicol (folhas 2EG, 1EG ou 0EG na zona interfoliar correspondentes a camadas com baixa, média e alta carga, respectivamente) variam com o tipo de cátion que satura a zona interfoliar. A homogeneidade da esmectita ao longo do perfil é a assinatura de um processo de alteração precoce em uma água lagunar supersaturada em calcita. A compactação durante o soterramento tornou a camada de bentonita um sistema fechado empobrecido em K no qual a ilitização diagenética foi inibida. Variações nas abundâncias de elementos maiores, menores e ETR no depósito maciço de argila sugere que este foi originado a partir de duas quedas sucessivas de cinza. A abundância de elementos incompatíveis é consistente com a de um vidro vulcânico fracionado a partir de um magma riolitico formado em um ambiente geológico de subducção/colisão.

Palavras-chave: bentonita, ETR, elementos incompatíveis, interestratificados, Uruguai.

\section{REFERENCES}

Altaner SP And Grim RE. 1990. Mineralogy, chemistry, and diagenesis of the Sucker Creek Formation (Miocene), eastern Oregon. Clays Clay Miner 38: $561-572$.

Altaner SP, Hower J, Whitney G And AronSON JL. 1984. Model for K-bentonite formation: evidence from zoned K-bentonites in the disturbed belt, Montana. Geology 12: 412-415.

Andreis RR, FERrando L And Herbst R. 1996. Terrenos Carboniferos y Pérmicos de Republica Oriental del Uruguay. In: EL SISTEMA PERMiCo EN LA Republica ARgentina y EN LA Republica Oriental del Uruguay. Academia Nacional del Uruguay, Cordoba, Argentina, p. 309-343.

AXELROD DI. 1981. Role of volcanism in climate and evolution. Geol Soc Amer Spec Paper 185: 59.

Barberena MC, Araujo DC, Lavina EL AND AzEVEDo SAK. 1985. O estado atual do conhecimento sobre tetrapodos permianos e triássicos do Brasil Meridional. In: Congresso BrasileIro De Paleontologia 8, Coletânea de trabalhos paleontológicos, Brasília, DF, Brasil, Ser Geol 27(2): 21-28. 

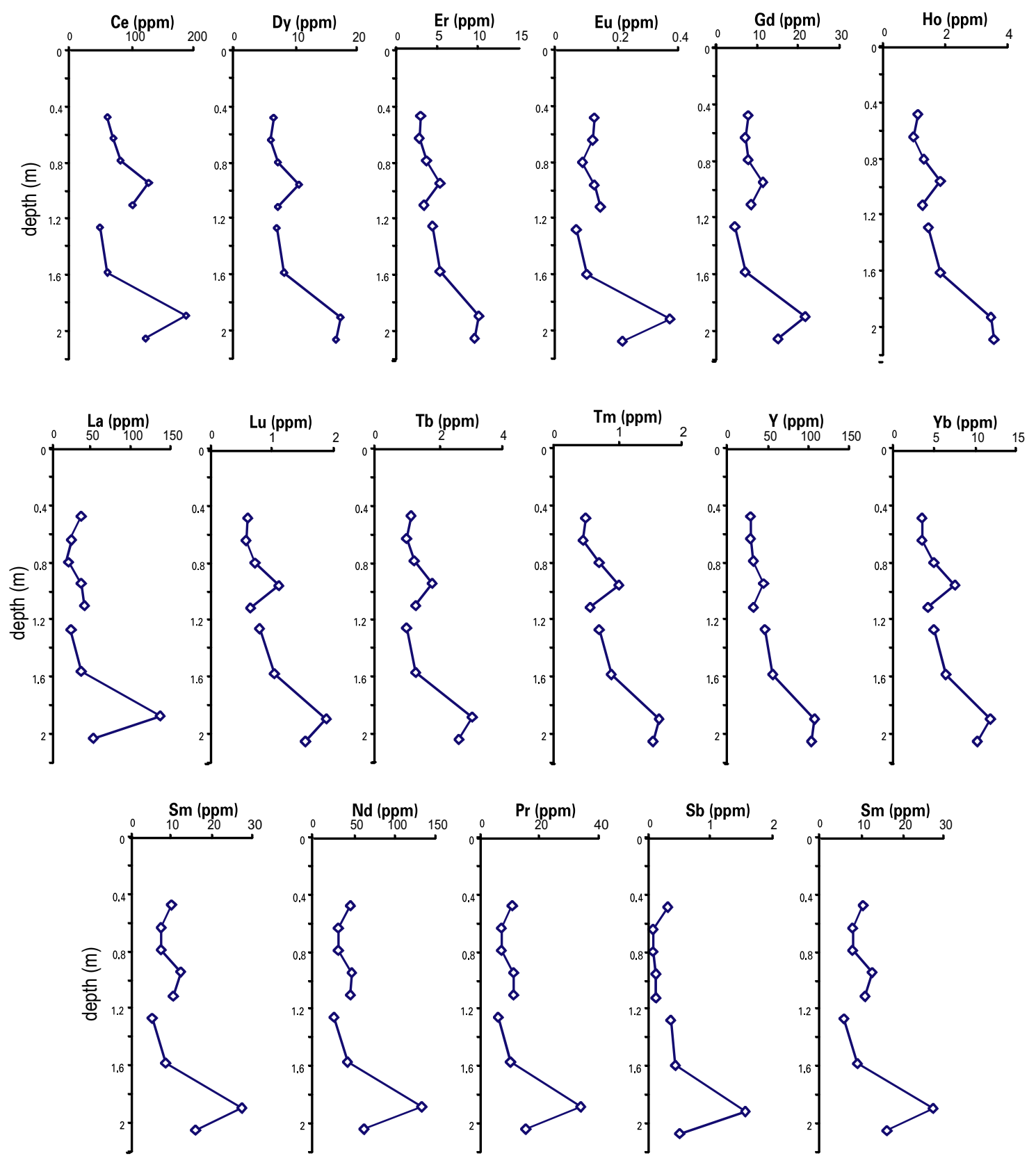

Fig. $5 d-$ GROUP 4 
Calarge LM, Meunier A And Formoso ML. 2002. A bentonite bed in the Acegua (RS, Brazil) and Melo (Uruguay) areas: a highly crystallized montmorillonite. J South Am Earth Sci 16: 187-198.

CHRISTIDIS GE. 1998. Comparative study of the mobility of major and trace elements during alteration of an andesite and a rhyolite to bentonite, in the islands of Milos and Kimolos, Aedean, Greece. Clays Clay Miner 46: 379-399.

Christidis GE, ScotT PW AND Marcopoulos T. 1995. Origin of the bentonite deposits of eastern Milos, Aegean, Greece: geological, mineralogical and geochemical evidence. Clays Clay Miner 43: 63-77.

Clayton T, Francis JE, Hillier SJ, Hodson F, SAUNDERS RA AND STONE J. 1996. The implication of reworking on the mineralogy and chemistry of lower Carboniferous K-bentonites. Clay Miner 31: 377-390.

EVEnsen NM, HAMilton PJ AND O'NiOns RK. 1978. Rare-earth abundances in chondritic meteorites. Geochim Cosmochim Acta 42: 1199-1212.

GoÑI JC. 1952. Etude minéralogique de quelques argiles de l'Uruguay. C.I.P.E.A. XIX Congresso Internacional de Geologia, Fasc XVIII: 47-56.

GRIM RE AND GÜVEN N. 1978. Bentonites, Geology, Mineralogy, Properties and Uses. Developments in Sedimentology 24, Elsevier, Amsterdam, Netherlands, $256 \mathrm{p}$.

HARDIE LA AND EUgSTER HP. 1970. The evolution of closed-basin brines. Mineral Soc Am Spec Pub 3: 273-290.

Heilman MD, Carter DL AND Gonzalez CL. 1965. The ethylene glycol monoethyl ether (EGME) technique for determining soil-surface area. Soil Sci 100: 409-413.

HeIn JR AND Scholl DW. 1978. Diagenesis and distribution of late Cenozoic volcanic sediment in the southern Bering Sea. Geol Soc Amer Bull 89: 197-210.

HufF WD AND Kolata DR. 1989. Correlation of K-bentonite beds by chemical fingerprinting using multivariate analysis. In: QUANTITATIVE DYNAMiC Stratigraphy. Cross TA (Ed), PrenticeHall, Englewood Cliffs, New Jersey, p. 567-577.
HufF WD AND TÜrkMENOGLÜ AG. 1981. Chemical characteristics and origin of Ordovician K-bentonites along the Cincinnati Arch. Clays Clay Miner 29: $113-123$.

Huff WD, Merriman RJ, Morgan DJ And RoBERTS B. 1993. Distribution and tectonic setting of Ordovician K-bentonites in the United Kingdom. Geol Mag 130: 93-100.

IÑIgUeZ A, ANDREIS RR AND ZALBA P. 1988. Eventos piroclasticos en la Formacion Tunas (Permico), Sierras Australes, provincia de Buenos Aires, Republica Argentina. Segundas Jornadas Geologicas Bonaerenses. Actas, Bahia Blanca, Argentina, p. 383-395.

JAGODZINSKI H. 1949. Eindimensionale Fehlordnung in Kristallen und ihr Einfluss auf die Röntgeninterferenzen. III. Vergleich der Berechnungen mit experimentellen Ergebnissen. Acta Crystall 2: 298-304.

JeAns CV, Merriman RJ AND Mitchell JG. 1977. Origin of Middle Jurassic and Lower Cretaceous fuller's earths in England. Clay Miner 12: 11-44.

JEANS CV, WRAY DS, MERRIMAN RJ AND FISHER MJ. 2000. Volcanogenic clays in Jurassic and Cretaceous strata of England and the North Sean Basin. Clay Miner 35: 25-55.

Juteau T AND MAURY R. 1997. Géologie de la croûte océanique: Pétrologie et dynamique endogène, Masson ed., 367 p.

Laviano R And Mongelli G. 1996. Geochemistry and mineralogy as indicators of parental affinity for Cenozoic bentonites: a case study from S. Croce Di Magliano (southern Apennines, Italy). Clay Miner 31: 391-401.

MoORE DM AND REYNOLDS RC. 1989. X-ray diffraction and the identification and analysis of clay minerals. Oxford, Oxford University Press, 198 p.

Pintaude DA AND Formoso MLL. 1972. Ocorrencia de Argila montmorilonitica em Acegua - RS Instituto Tecnologico do Rio Grande do Sul. Bol $57,40 \mathrm{p}$.

PlançOn A AND Drits VA. 2000. Phase analysis of clays using an expert system calculation programs for X-ray diffraction by two- or three-component mixed-layer minerals. Clays Clay Miner 48: 57-62.

RAmos VA. 1984. Patagonia: Un continente paleozoi- 
co a la deriva? IX Congreso Geológico Argentino (S.C. Bariloche) Actas I: 311-325.

REYNOLDS RC. 1992. X-ray diffraction studies of illite/smectite from rocks, $<1 \mu \mathrm{m}$ randomly oriented powders, and $<1 \mu \mathrm{m}$ oriented powder aggregates: the absence of laboratory induced artefacts. Clays Clay Miner 40: 387-396.

Sato T, Watanabe T And Otsuka R. 1992. Effects of layer charge, charge location, and energy change on expansion properties of dioctahedral smectites. Clays Clay Miner 40: 103-113.
Winchester JA AND FLOYD PA. 1977. Geochemical discrimination of different magma series and their differentiation products using immobile elements. Chem Geol 20: 235-243.

WRAY DS. 1995. Origin of clay-rich beds in Turonian chalks from lower Saxony, Germany - a rare-earth element study. Chem Geol 119: 161-173.

ZIELINSKI RA. 1982. The mobility of uranium and other elements during alteration of rhyolite ash to montmorillonite: a case study in the Troublesome Formation, Colorado, USA. Chem Geol 35: 185-204. 